\title{
Lead Transport into Bayou Trepagnier Wetlands in Louisiana, USA
}

\author{
Margaret S. Devall,* Leonard B. Thien, Erik Ellgaard, and George Flowers
}

\begin{abstract}
Establishment of a petroleum refinery in 1916 near the headwaters of Bayou Trepagnier with subsequent dredging of the bayou resulted in spoil banks containing high levels of $\mathbf{P b}$. A large swamp abuts the eastern bank of the bayou. Cores were taken from 15 baldcypress [Taxodium distichum (L.) Richard] trees growing in the swamp along a 610-m transect (nine trees) and a 183-m transect (six trees) running perpendicular from the spoil bank. The cores were crossdated, annual rings were measured, and 5-yr segments of the cores were prepared and analyzed for heavy metals. Soil samples were collected along one transect and analyzed for metals. Levels of $\mathbf{P b}$ in Bayou Trepagnier swamp trees were compared to levels in nine baldcypress trees growing along Stinking Bayou, a reference area. During the last $100 \mathrm{yr}, \mathbf{P b}$ in growth rings of swamp baldcypress trees averaged $8.6 \mathrm{mg} / \mathrm{kg}$ (SD 4.88) along one transect and $7.9 \mathrm{mg} / \mathrm{kg}$ (SD 5.39) along the other. Lead in the soil along the first transect dropped from $>2700 \mathrm{mg} / \mathrm{kg}$ (spoil bank) to $10 \mathrm{mg} / \mathrm{kg}$ at $420 \mathrm{~m}$ into the swamp. Baldcypress trees growing near the refinery on the spoil bank along Bayou Trepagnier (covered in an earlier study) averaged $4.5 \mathrm{mg} / \mathrm{kg} \mathrm{Pb}$, and trees along Stinking Bayou averaged $2.1 \mathrm{mg} / \mathrm{kg}$. Trees in the swamp soil with 10 to $425 \mathrm{mg} /$ $\mathrm{kg} \mathrm{Pb}$ concentrated much more $\mathrm{Pb}$ than trees growing on the heavily polluted bank. Greater uptake of Pb by trees in the swamp is discussed in terms of soil dynamics and Pb sources.
\end{abstract}

$\mathrm{I}_{\mathrm{m}}^{\mathrm{N}}$ RECENT YEARS, increasingly higher levels of heavy metals (e.g., $\mathrm{Pb}, \mathrm{Zn}, \mathrm{Cu}, \mathrm{Cd}$, etc.) have become widespread in ecosystems as a result of man's activities (Baes and McLaughlin, 1984; Bondietti et al., 1989; Donnelly et al., 1990; Forget and Zayed, 1995; Wimmer and McLaughlin, 1996; Padilla and Anderson, 2002). As the use and release of metals into the atmosphere has escalated (Nriagu, 1990) the emission of some metals now equals or is greater than natural emissions (Hughes, 1981; Baes and McLaughlin, 1984; Bondietti et al., 1989; Martin and Bullock, 1994). Sometimes these metals are available for transport through the root systems of plants (Symeonides, 1979). In suitable tree species, dendrochemistry can provide a record of metal pollution/environmental concentrations unavailable from other sources and has been a useful tool in biomonitoring environmental metals concentrations (Thomas et al., 1996; Watmough, 1999; Anderson et al., 2000; Padilla and Anderson, 2002).

An important consideration in dendrochemical studies is the possibility of radial movement of ions across

M.S. Devall, USDA Forest Service, Center for Bottomland Hardwoods Research, P.O. Box 227, Stoneville, MS 38776. L.B. Thien, Cell and Molecular Biology Department, Tulane University, New Orleans, LA 70118. G. Flowers, Department of Geology, Tulane University, New Orleans, LA 70118. E. Ellgaard (deceased), Cell and Molecular Biology Department, Tulane University, New Orleans, LA 70118. Received 1 June 2005. *Corresponding author (mdevall@fs.fed.us).

Published in J. Environ. Qual. 35:758-765 (2006).

Technical Reports: Heavy Metals in the Environment doi:10.2134/jeq2005.0217

(c) ASA, CSSA, SSSA

677 S. Segoe Rd., Madison, WI 53711 USA annual rings after uptake. Radial movement depends on the affinity of the element to bind to or be incorporated into xylem cell structures. Lead has low mobility across annual rings compared with other elements (Cutter and Guyette, 1993). Lateral translocation is usually less important in conifers than in angiosperms because of the more primitive wood of conifers, which contains few short ray cells, thus reducing lateral movement (Baes and Ragsdale, 1981; Lewis, 1995). However, Lepp and Dollard (1974) indicated that $\mathrm{Pb}$ could move from the bark to the xylem of trees. Significant $\mathrm{Pb}$ concentrations were found in the xylem of red spruce (Picea rubens Sarg.) seedlings, formed during years of $\mathrm{Pb}$ exclusion (Donnelly et al., 1990), although the authors suggest that longer-term trends might be preserved. Symeonides (1979) concluded that lateral translocation of $\mathrm{Pb}$ in the boles of Scotch pine (Pinus sylvestris L.) was of minor significance. Baes and McLaughlin (1984) suggest that conifers could serve as bioindicators of trace metal input to forest ecosystems. Guyette et al. (1991) and Guyette and McGinnes (1987) found that eastern red-cedar (Juniperus virginiana L.) was well suited for monitoring changes in $\mathrm{Pb}$ in a mining district.

Baldcypress has characteristics that make it attractive for chemical analysis. It is a long-lived conifer and the wood has a slow transition to heartwood (Thomas et al., 1996). Latimer et al. (1996) analyzed growth rings of baldcypress trees on the spoil bank of Bayou Trepagnier (not in the swamp per se) to provide a chronology of $\mathrm{Pb}$ pollution. Concentrations of $\mathrm{Pb}$ in the wood of baldcypress showed that $\mathrm{Pb}$ levels increased in the early 1920s after the plant opened and during dredging episodes in the 1950s, then slowly declined in recent decades. The baldcypress trees along Bayou Trepagnier displayed a marked difference in levels of $\mathrm{Pb}$ dependent on their proximity to the pollution point source. This article documents the accumulation of $\mathrm{Pb}$ in baldcypress trees of the surrounding cypress-tupelo (Nyssa aquatica L.) swamp, adjacent to the bank of the bayou.

\section{MATERIALS AND METHODS}

\section{Study Area}

Bayou Trepagnier (4.90 km in length) is located between the Mississippi River and Lake Pontchartrain, Louisiana in St. Charles Parish, and it merges with Bayou LaBranche a short distance before it enters the lake. These two bayous extend from the backslope of the Mississippi River's natural levees and drain into Lake Pontchartrain. During the second decade of the 20th century, industrial complexes, chiefly those related to petroleum, replaced farms and plantations on the higher land along the Mississippi River in St. Charles Parish. In 1916 a petroleum refinery, which eventually became the largest one in the parish, was built near the headwaters of Bayou Trepagnier. The refinery was expanded and modernized in 1930, at which time substantial quantities of pollutants $(\mathrm{Pb}, \mathrm{Zn}, \mathrm{Cr}$, and 
polyaromatic hydrocarbons) were diverted into Bayou Trepagnier. Major dredging of the bayou occurred in the 1950s resulting in spoil banks 2 to $3 \mathrm{~m}$ in height along the length of the bayou at various distances up to $150 \mathrm{~m}$ from the bayou. Around this time the Good Hope Oil and Gas Field was established in the area, then several oil and gas refineries were built along the Mississippi River in St. Charles Parish (Lousiana Dep. of Environ. Qual., 1989; Pearson et al., 1993; Latimer et al., 1996).

Bayou Trepagnier is listed as a contaminated body of water by the Louisiana Department of Environmental Quality (Lousiana Dep. of Environ. Qual., 1989); it is also designated as a scenic stream by the state. In the area immediately adjacent to Bayou Trepagnier, two distinct soil environments can be delineated: (i) emergent soils derived from weathered dredge spoil; and (ii) organic-rich wetland soils, which are fre- quently inundated due to changes in water level in Lake Pontchartrain and discharge of urban runoff from the city of Norco, LA. Spoil banks, which were created during various dredging episodes, are found on both banks of the bayou, but the majority of the spoil (waste material removed during dredging of the bayou) is found on the western bank (Fig. 1). Spoil banks are generally emergent, except during major floods associated with the passage of hurricanes and Bonnet Carre' Spillway openings.

\section{Methods}

A $4.9-\mathrm{km}$ transect with stations at 30.4-m intervals had previously been established along Bayou Trepagnier, with Station 0 closest to the refinery (Latimer et al., 1996). We cored baldcypress trees growing in the swamp away from the spoil

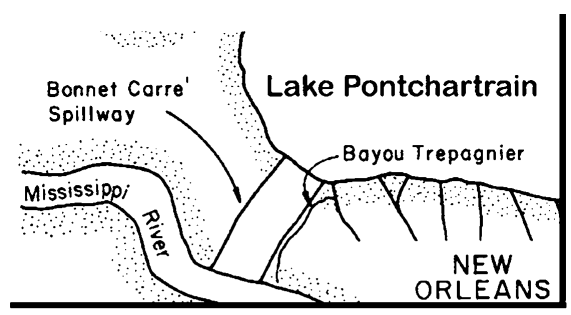

Bonnet Carre' Spillway
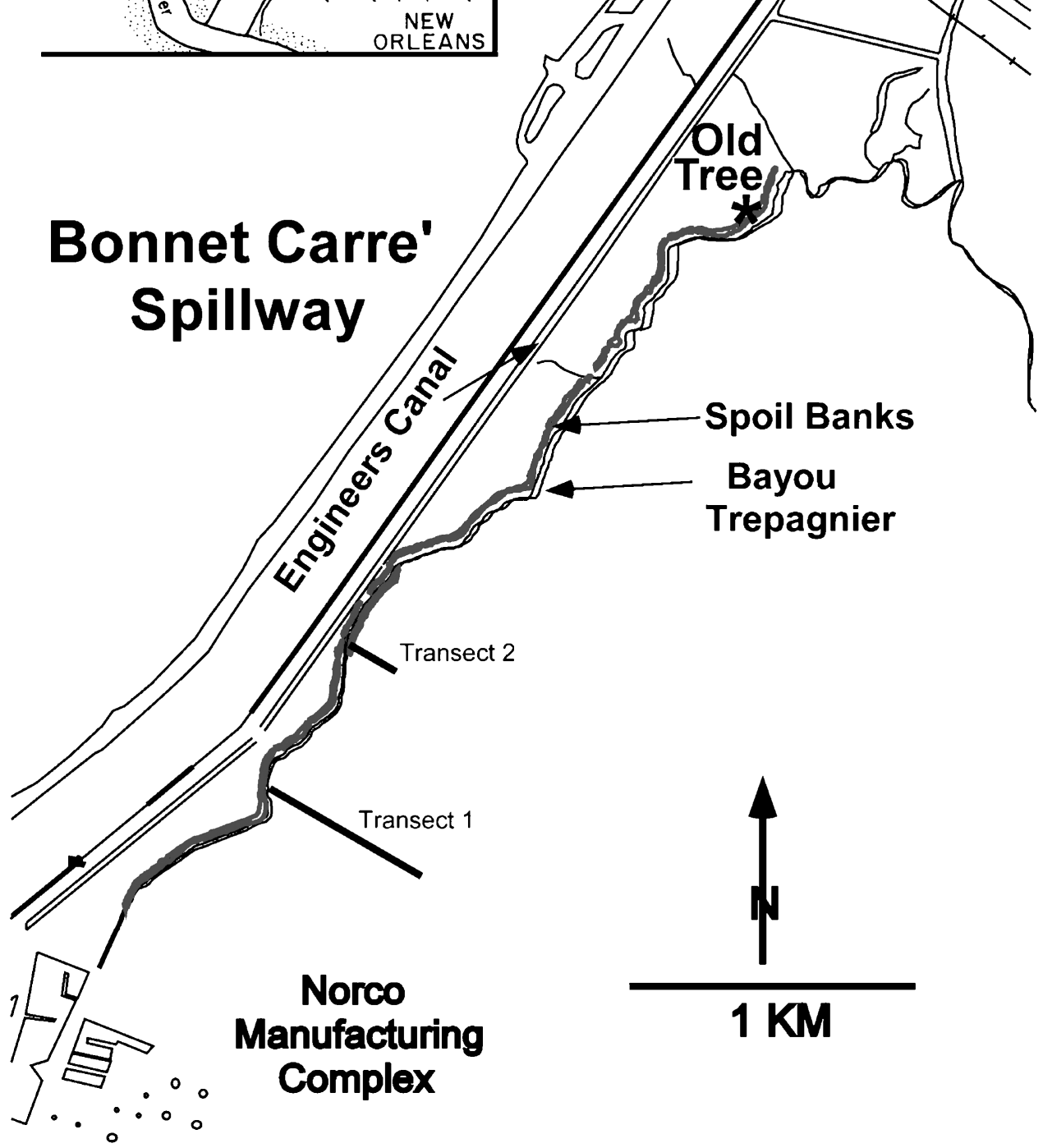

Fig. 1. Map of Bayou Trepagnier near New Orleans, LA, showing the spoil banks and the Norco Manufacturing Complex. Bayou Trepagnier merges with Bayou LaBranche a short distance from the lake. 
bank, along a 610-m transect (Transect 1, nine trees) and a 183-m transect (Transect 2, six trees) perpendicular to Bayou Trepagnier. Both these transects extend generally west to east from the base of the spoil bank, Transect 1 approximately $912 \mathrm{~m}$ downstream from the point source, and Transect 2 $1642 \mathrm{~m}$ from the point source (Fig. 1). For baseline information we also cored a 300-yr-old baldcypress tree near Station 129 (Fig. 1) and nine baldcypress trees growing along Stinking Bayou, a bayou that empties into Lake Pontchartrain $35 \mathrm{~km}$ north of Bayou Trepagnier, on the western side of the lake. Stinking Bayou was selected as a reference area because it is in the same general area as Bayou Trepagnier, with similar soil and vegetation, but is relatively isolated. Few people live in the area and there is no industrial activity in the watershed.

At least two cores were taken from each baldcypress tree using a 5-mm diameter Teflon-coated increment borer. The borer was cleaned with pieces of fresh dry cotton cloth after each sample was extracted. Cores were immediately placed in plastic straws. All other procedures were carefully conducted to avoid contamination (Latimer et al., 1996). The cores were air-dried, mounted in clamps, and hand sanded with three grades of sandpaper. The cores were then polished with lamb's wool and compressed air was used to blow away sawdust or any grains of sand. Cores from the transects, the reference and the bank of Bayou Trepagnier (Latimer et al., 1996) were prepared the same way. Cores with indistinct rings, several breaks, or rotten areas were not used. The cores were placed on a stage equipped with a linear encoder and the annual rings were measured to within $0.001 \mathrm{~mm}$ under a stereomicroscope and video monitor. Identification of marker rings helped establish correct crossdating. Measuring of the rings and crossdating were accomplished with the assistance of the DYNACLIM computer software programs (Van Deusen, 1993).

Crossdated cores were marked and then cut into 5-yr intervals with a minimum weight of use set at $0.100 \mathrm{~g}$. The concentration of metals was ascribed to the year that was the midpoint in each interval. After grinding to 20 mesh size in a Wiley mill, the samples were pressed into $13 \mathrm{~mm}, 8 \mathrm{mg}$ wafers with a $10-\mathrm{mm}$ die normally used for spectrometry. An energy dispersive ED-XRF Spectro X-Lab fluorescent spectrometry with Mylar film ultra-thin window was used to analyze the samples for heavy metals (Gilfrich et al., 1991; MacLauchlan et al., 1987; Kocman et al., 1991; Thomas et al., 1996). The methods were identical to those in the earlier study (Latimer et al., 1996). The detection limit for $\mathrm{Pb}$ was $1 \mathrm{mg} / \mathrm{kg}$. Concentrations below the detection limit were averaged as 0 (Guyette et al., 1991).

Soil organic material was scraped from 21 randomly located sites near Transect 1 along a line beginning west of the transect, starting at Engineers Canal west of Bayou Trepagnier and extending east. A 0.5 - $\mathrm{L}$ sample of soil was collected from the upper $10 \mathrm{~cm}$ of soil at each site and analyzed for concentration of $\mathrm{Pb}, \mathrm{Zn}, \mathrm{Cr}$, and $\mathrm{Cu}$ using a method derived from USEPA Method 3052, microwave-assisted total digestion with ICP analysis using method 6010B. The method was modified to optimize dissolution of the samples.

\section{RESULTS AND DISCUSSION}

The wetland soils adjacent to Bayou Trepagnier spoil banks had detectable concentrations of $\mathrm{Pb}, \mathrm{Zn}, \mathrm{Cr}$, and to a lesser degree $\mathrm{Cu}$. Average values (Table 1) for these metals greatly exceed values given for the average shale (Turekian and Wedepohl, 1961), the standard used by geochemists for the expected value for metals in muddy sediments. Of the metals analyzed, $\mathrm{Pb}$ is significantly enriched in both wetland soils and spoil banks because
Table 1. Summary statistics for total heavy metal concentrations $(\mathrm{mg} / \mathrm{kg})$ in Bayou Trepagnier watershed soils. Values given for the average shale are taken from Turekian and Wedepohl (1961).

\begin{tabular}{|c|c|c|c|c|}
\hline Metal & $\mathbf{P b}$ & $\mathbf{Z n}$ & $\mathbf{C r}$ & $\mathbf{C u}$ \\
\hline & & - & & - \\
\hline$N$ & 457 & 457 & 457 & 457 \\
\hline Mean & 598 & 177 & 148 & 34 \\
\hline Median & 210 & 138 & 72 & 29 \\
\hline SD & 1195 & 122 & 379 & 24 \\
\hline Minimum & $<\mathbf{2 0}$ & 11 & 26 & 5 \\
\hline Maximum & 14245 & 1140 & 6934 & 264 \\
\hline 5th percentile & $<\mathbf{2 0}$ & 76 & 43 & 14 \\
\hline 95th percentile & 2430 & 389 & 432 & 65 \\
\hline Avg. shale & 20 & 95 & 90 & 45 \\
\hline
\end{tabular}

of its high concentration in the refinery waste (Lousiana Dep. of Environ. Qual., 1989) stream before passage of the Clean Water Act in 1972. Anomalously high values of $\mathrm{Zn}, \mathrm{Cr}$, and $\mathrm{Cu}$ are also found in the watershed, but the degree of enrichment is on average less than two times the average shale value (Table 1 ). The standard deviations are high (Table 1) because all areas are not uniformly impacted. Along the spoil bank where sediments were dredged up and deposited on shore, extremely high values for the metals are found. As one moves away from the spoil bank, the values drop to background. The statistics, including the percentiles, indicate skewed distributions with high variability.

Marcantonio et al. $(1998,2000)$ used $\mathrm{Pb}$ isotopic ratios to demonstrate that the $\mathrm{Pb}$ in the spoil banks, the main source of contamination in the ecosystem, originated from ore bodies in Missouri, as well as from the natural environment of Bayou Trepagnier. Marcantonio et al. (1998) concluded that local hydrological and chemical processes determine the amount of contaminated lead in each tree. The isotope data is consistent with the hypothesis of Flowers et al. (1996) of transport of Pb-contaminated soil from the spoil bank into the aquatic community.

Lead concentrations in a single baldcypress tree growing along Bayou Trepagnier present an example of changes in Pb levels in recent years (Fig. 2). The sharp increase in $\mathrm{Pb}$ beginning around 1920 correlates with the establishment of a petroleum plant, its subsequent expansion, and several dredging episodes. The concentration of $\mathrm{Pb}$ has declined in recent years. At the intersection of the spoil banks on the east side of Bayou Trepagnier and the cypress-tupelo swamp, $\mathrm{Pb}$ in the soil along Transect 1 "tails off" from $>2700 \mathrm{mg} / \mathrm{kg}$ on the spoil bank to $10 \mathrm{mg} / \mathrm{kg}$ at the east end of the transect (Fig. 3). In contrast, there was no trend in $\mathrm{Pb}$ concentration in the growth rings of the nine baldcypress trees along this transect in the cypress-tupelo swamp. Lead concentrations in the growth rings of the trees averaged $8.6 \mathrm{mg} / \mathrm{kg}$ along Transect 1 (1893-1997, Fig. 4) and varied from 7.9 to $10.5 \mathrm{mg} / \mathrm{kg}$. There was very low correlation $(-0.03$ to 0.14$)$ between $\mathrm{mg} / \mathrm{kg}$ lead and ringwidth for trees growing along the transect. This suggests that the $\mathrm{Pb}$ was not affecting radial growth, but $\mathrm{Pb}$ can compromise roots without showing up in the wood, and differences in soil nutrients and $\mathrm{O}_{2}$ levels could be making up for the detrimental effects of $\mathrm{Pb}$. Along Transect $2, \mathrm{~Pb}$ concentration in tree rings of six baldcypress 


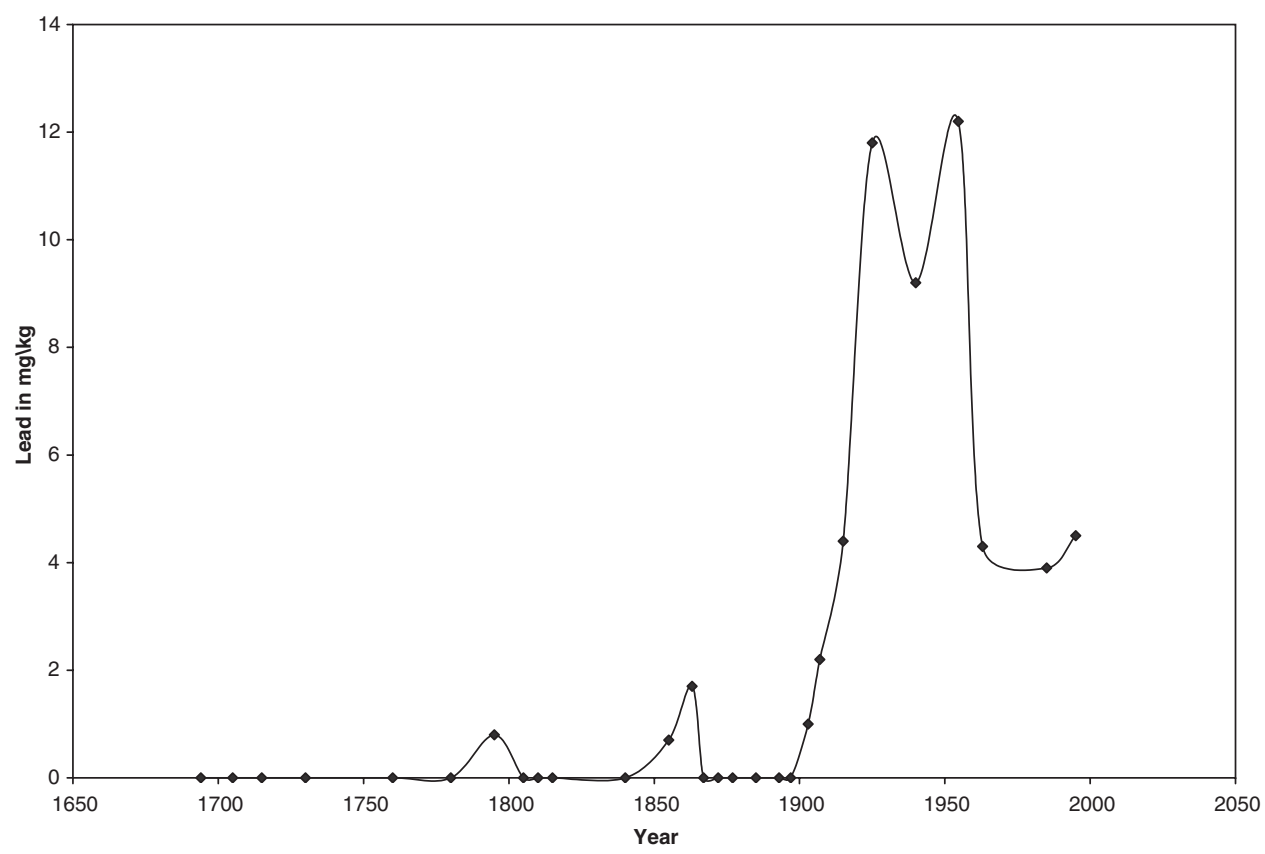

Fig. 2. Lead (1687-1995) in the tree rings of a 300 + yr-old baldcypress tree growing along Bayou Trepagnier, downstream from the pollution point. The sharp increase of $\mathrm{Pb}$ beginning around 1920 correlates with the establishment of a petroleum plant, its subsequent expansion, and several dredging episodes. The detection limit is $1 \mathrm{mg} / \mathrm{kg}$.

trees averaged $7.8 \mathrm{mg} / \mathrm{kg}(6.1-9.2 \mathrm{mg} / \mathrm{kg}$, Fig. 5). In contrast, the baldcypress trees growing on the spoil bank in the upper portions of Bayou Trepagnier averaged $4.5 \mathrm{mg} / \mathrm{kg} \mathrm{Pb}(3.2-5.5 \mathrm{mg} / \mathrm{kg})$ and trees along the lower portion of the bayou averaged $2.2 \mathrm{mg} / \mathrm{kg} \mathrm{Pb}(1.7-2.8$, Latimer et al., 1996).

The level of $\mathrm{Pb}$ in trees along Stinking Bayou, the reference area $(2.6 \mathrm{mg} / \mathrm{kg} \mathrm{Pb}, 1.1-6.5 \mathrm{mg} / \mathrm{kg})$, was sig- nificantly different from the levels in trees along the two transects (Table 2). The levels of $\mathrm{Pb}$ in trees of the two transects were significantly different from the level found by Latimer et al. (1996) in trees on the bank of Bayou Trepagnier (ANOVA, $F=30.7, P<0.0001$, root mean squared error $=1.89$ ). Figure 6 shows $\mathrm{Pb}$ pollution during the last century in trees of Transect 1 (nine trees) and Transect 2 (six trees) and Stinking Bayou (nine

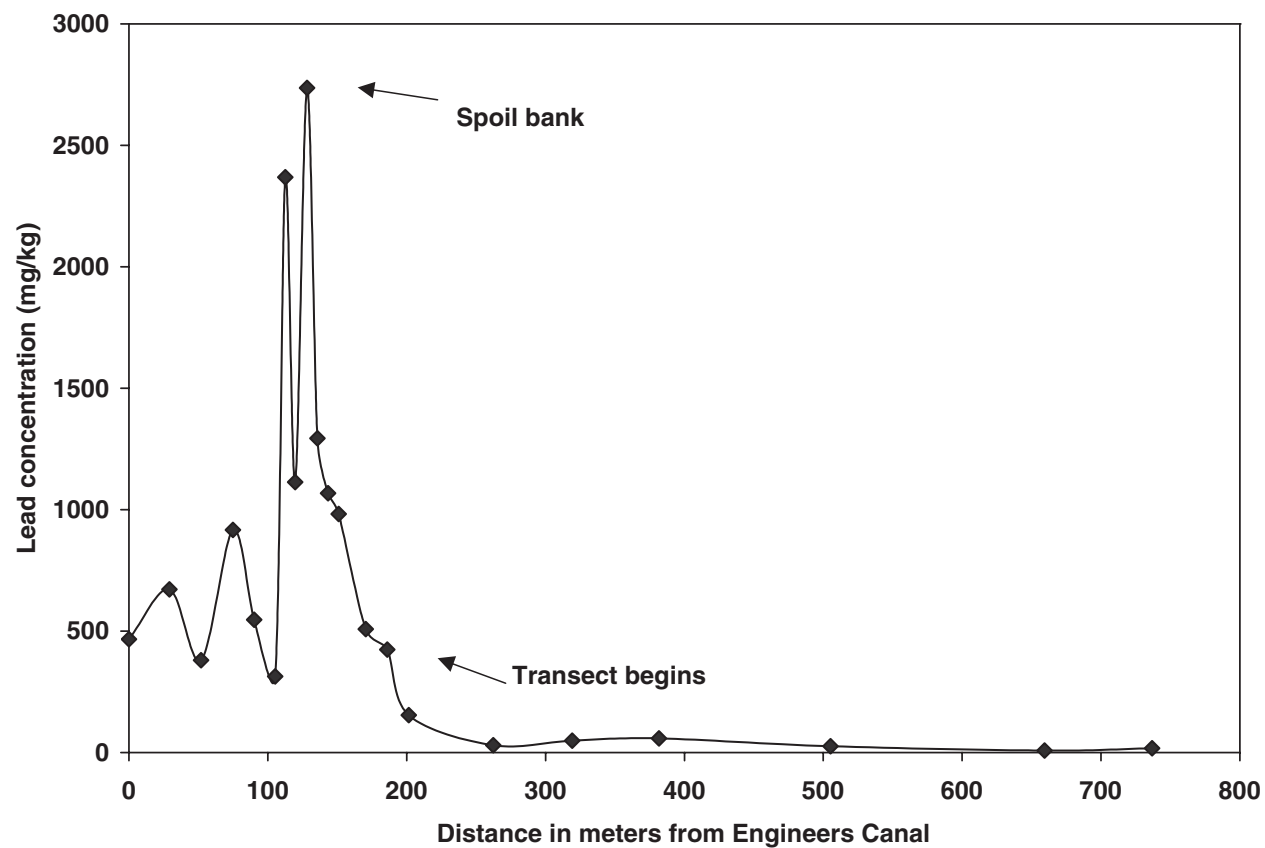

Fig. 3. Levels of $\mathrm{Pb}$ in the top $10 \mathrm{~cm}$ of soil along Transect 1, eastward from Engineer's Canal $(0 \mathrm{~m})$, which is west of Bayou Trepagnier. Transect 1 begins at the base of the spoil bank along Bayou Trepagnier. Soil organic material was scraped from 21 randomly located sites along a line beginning west of Transect 1, starting at Engineers Canal west of Bayou Trepagnier and extending east into the swamp, and a 0.5-L sample of soil was collected at each site and analyzed. The detection limit is $1 \mathrm{mg} / \mathrm{kg}$. 


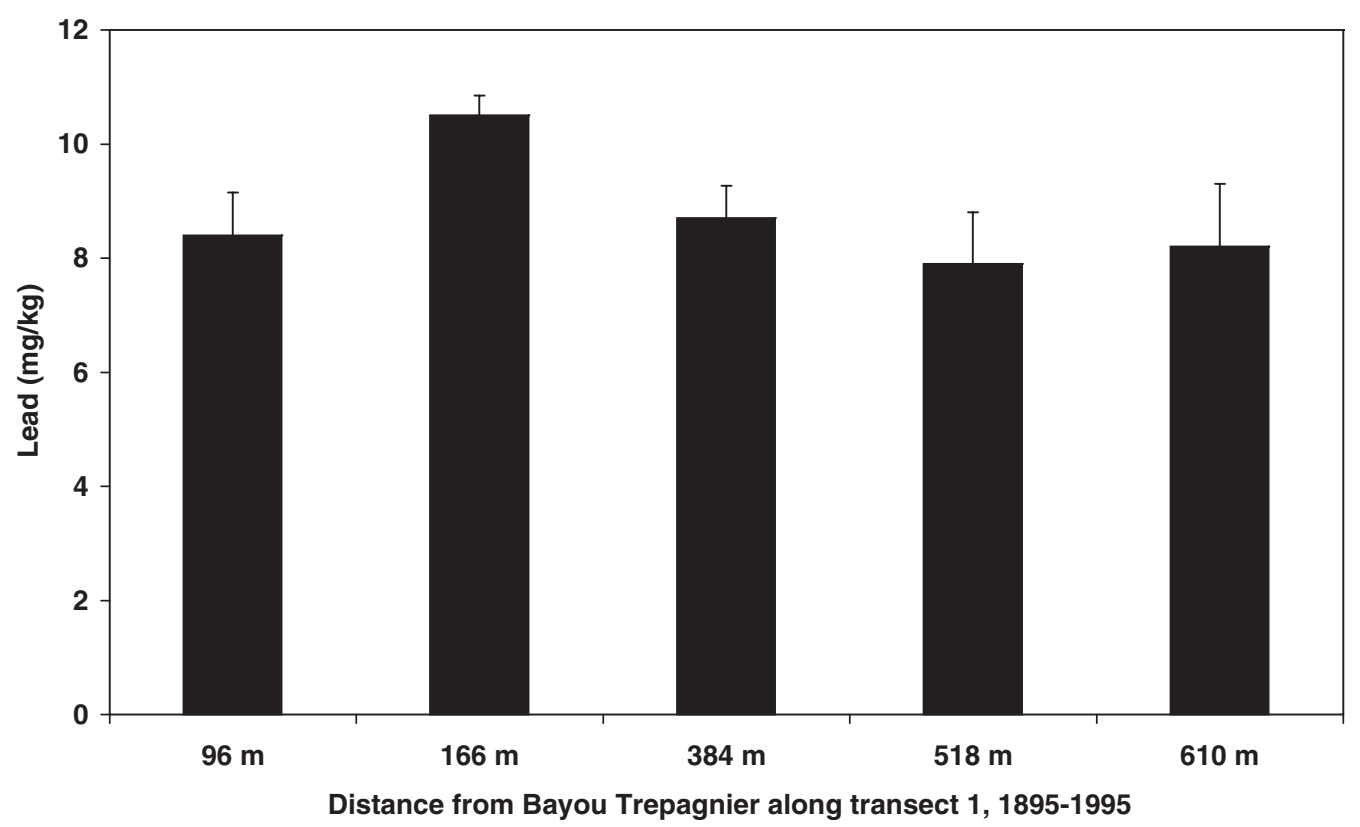

Fig. 4. Lead in tree rings of 16 cores from baldcypress trees, 1893-1997, along Transect 1 running perpendicular to Bayou Trepagnier into the adjacent baldcypress-tupelo community; distance from the edge of the spoil bank on the east side of the bayou indicated by numerals under bars. Error bars indicate standard error. The level of $\mathrm{Pb}$ in trees along Stinking Bayou, the reference area, was significantly different from the levels in trees along the two transects (see Table 2). The detection limit is $1 \mathrm{mg} / \mathrm{kg}$.

trees) by presenting the $\mathrm{Pb}$ concentrations in 5-yr chronological segments of growth rings (also see Table 2). There appears to be minor translocation of $\mathrm{Pb}$ to older wood in the trees, otherwise one would expect $\mathrm{Pb}$ levels before the 20th century in trees from the two transects and from Stinking Bayou to be about the same. Trees in Transects 1 and 2 display the highest $\mathrm{Pb}$ concentrations during the 1950s and 1960s after major dredging of the bayou occurred. Polluted soil was probably more easily washed into the swamp when the spoil banks were recently formed. The highest $\mathrm{Pb}$ levels of Stinking Bayou occurred during the late 1920s and may be associated with soil disturbance due to harvest of timber in the area and perhaps some accumulated $\mathrm{Pb}$ in the soil.

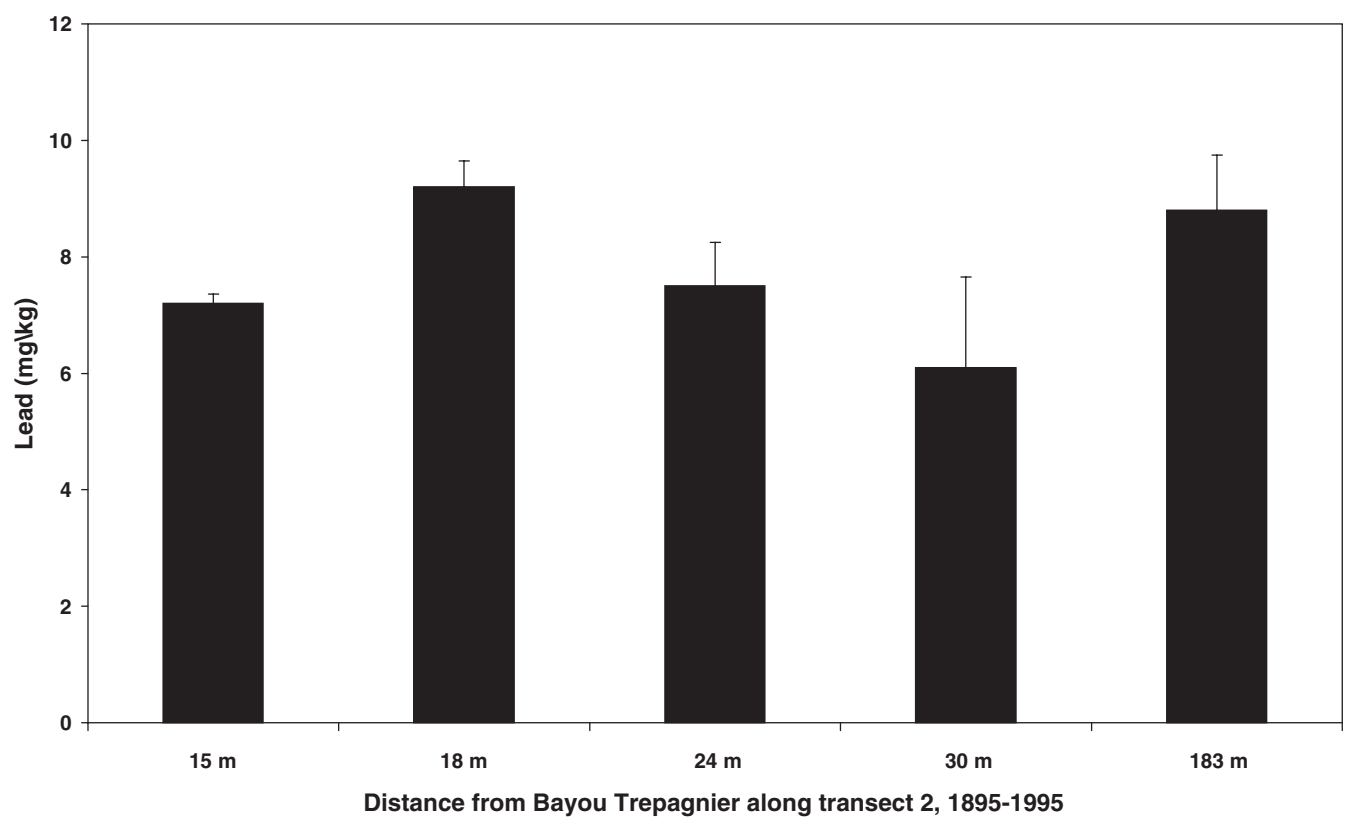

Fig. 5. Lead in tree rings of 12 cores from baldcypress trees, 1893-1997, along Transect 2 running perpendicular to Bayou Trepagnier into the adjacent baldcypress-tupelo community; distance from the spoil bank on the east side of the bayou indicated by numerals under bars. Error bars indicate standard error. The level of $\mathrm{Pb}$ in trees along Stinking Bayou, the reference area, was significantly different from the levels in trees along the two transects (see Table 2). The detection limit is $1 \mathrm{mg} / \mathrm{kg}$. 
Table 2. Mean levels of $\mathrm{Pb}(\mathrm{mg} / \mathrm{kg})$ in 5-yr segments of annual rings of baldcypress [Taxodium distichum (L.) Richard] trees from three sites: Transect 1 (nine trees), Transect 2 (six trees), and Stinking Bayou (nine trees), the reference area. Transects 1 and 2 are perpendicular to Bayou Trepagnier, located between the Mississippi River and Lake Pontchartrain, and Stinking Bayou empties into Lake Pontchartrain $35 \mathrm{~km}$ north of the polluted site. Levels of Pb compared using one-way analysis of variance. Where the $F$-statistic is significant at the 0.05 level, Tukey's test was applied to separate means (separately for each 5-yr period). Means with the same letter (a, b, c) are not significantly different. RMSE is root mean squared error.

\begin{tabular}{|c|c|c|c|c|c|c|}
\hline Mid-year & Transect 1 & Transect 2 & Stinking Bayou & $\boldsymbol{F}$ & $P$ value & RMSE \\
\hline 1992 & $6.2 \mathrm{a}$ & $6.5 \mathrm{a}$ & $1.1 \mathrm{~b}$ & 6.48 & 0.004 & 3.64 \\
\hline 1987 & $5.4 \mathrm{a}$ & $6.1 \mathrm{a}$ & $1.5 \mathrm{~b}$ & 5.18 & 0.011 & 3.12 \\
\hline 1982 & $5.4 \mathrm{a}$ & $7.1 \mathrm{a}$ & $2.5 \mathrm{~b}$ & 9.23 & 0.001 & 2.78 \\
\hline 1977 & 7.4 & 4.6 & 3.9 & 1.85 & 0.174 & 4.95 \\
\hline 1972 & 10.2 a & 8.8 a & $2.2 \mathrm{~b}$ & 10.47 & 0.000 & 4.41 \\
\hline 1967 & $9.8 \mathrm{a}$ & $10.2 \mathrm{a}$ & $3.4 \mathrm{~b}$ & 3.92 & 0.029 & 6.30 \\
\hline 1962 & $9.9 \mathrm{a}$ & $10.5 \mathrm{a}$ & $2.2 \mathrm{~b}$ & 13.34 & $<\mathbf{0 . 0 0 0}$ & 4.14 \\
\hline 1957 & $9.2 \mathrm{a}$ & $14.0 \mathrm{a}$ & $3.1 \mathrm{~b}$ & 9.03 & 0.001 & 5.74 \\
\hline 1952 & $9.0 \mathrm{a}$ & 10.1 a & $2.9 \mathrm{~b}$ & 7.84 & 0.002 & 4.16 \\
\hline 1947 & $9.6 \mathrm{a}$ & $12.3 \mathrm{a}$ & $2.5 \mathrm{~b}$ & $\mathbf{7 . 6 9}$ & 0.002 & 5.73 \\
\hline 1942 & $8.1 \mathrm{a}$ & $5.8 \mathrm{~b}$ & $2.1 \mathrm{c}$ & 20.10 & $<\mathbf{0 . 0 0 0}$ & 2.08 \\
\hline 1937 & $8.1 \mathrm{a}$ & $6.6 \mathrm{a}$ & $1.7 \mathrm{~b}$ & $\mathbf{1 1 . 1 2}$ & $<\mathbf{0 . 0 0 0}$ & 2.87 \\
\hline 1932 & $7.8 \mathrm{a}$ & $6.8 \mathrm{a}$ & $2.1 \mathrm{~b}$ & 8.26 & 0.002 & 2.95 \\
\hline 1927 & 8.7 & 6.0 & 6.5 & 1.38 & 0.272 & 3.92 \\
\hline 1922 & $9.7 \mathrm{a}$ & 7.3 a b & $1.5 \mathrm{~b}$ & 3.79 & 0.040 & 4.72 \\
\hline 75-yr avg. & $8.3 \mathrm{a}$ & $8.2 \mathrm{a}$ & $2.6 \mathrm{~b}$ & 41.26 & $<\mathbf{0 . 0 0 0}$ & 1.96 \\
\hline
\end{tabular}

Why is there greater uptake of $\mathrm{Pb}$ in baldcypress trees growing in the cypress-tupelo swamp adjacent to the spoil banks, with 10 to $424 \mathrm{mg} / \mathrm{kg} \mathrm{Pb}$ in the soil versus trees growing on the bank (Latimer et al., 1996) containing $>2700 \mathrm{mg} / \mathrm{kg} \mathrm{Pb}$ (Fig. 3)? Flowers et al. (1996, 1997) demonstrated (with elutriate tests performed with bayou water and spoil bank soil) that $\mathrm{Pb}$ is easily released from the soil when it is in contact with bayou water. They suggested that soil is dispersed from the spoil banks in storms, flooding, hurricanes, and so forth into the adjoining plant communities, causing periodic shock loads to the swamp. Bayou Trepagnier is a brackish bayou and sulfate-reducing bacteria are likely generating acid volatile sulfides from the sulfate in the brackish water, and these acid volatile sulfides are capable of scavenging dissolved heavy metals from the water (Di Toro et al., 1991). The precipitates formed in this way are very insoluble as long as reducing conditions are maintained (Gambrell, 1994), but when sulfides in the sediments are oxidized, sulfuric acid is generated

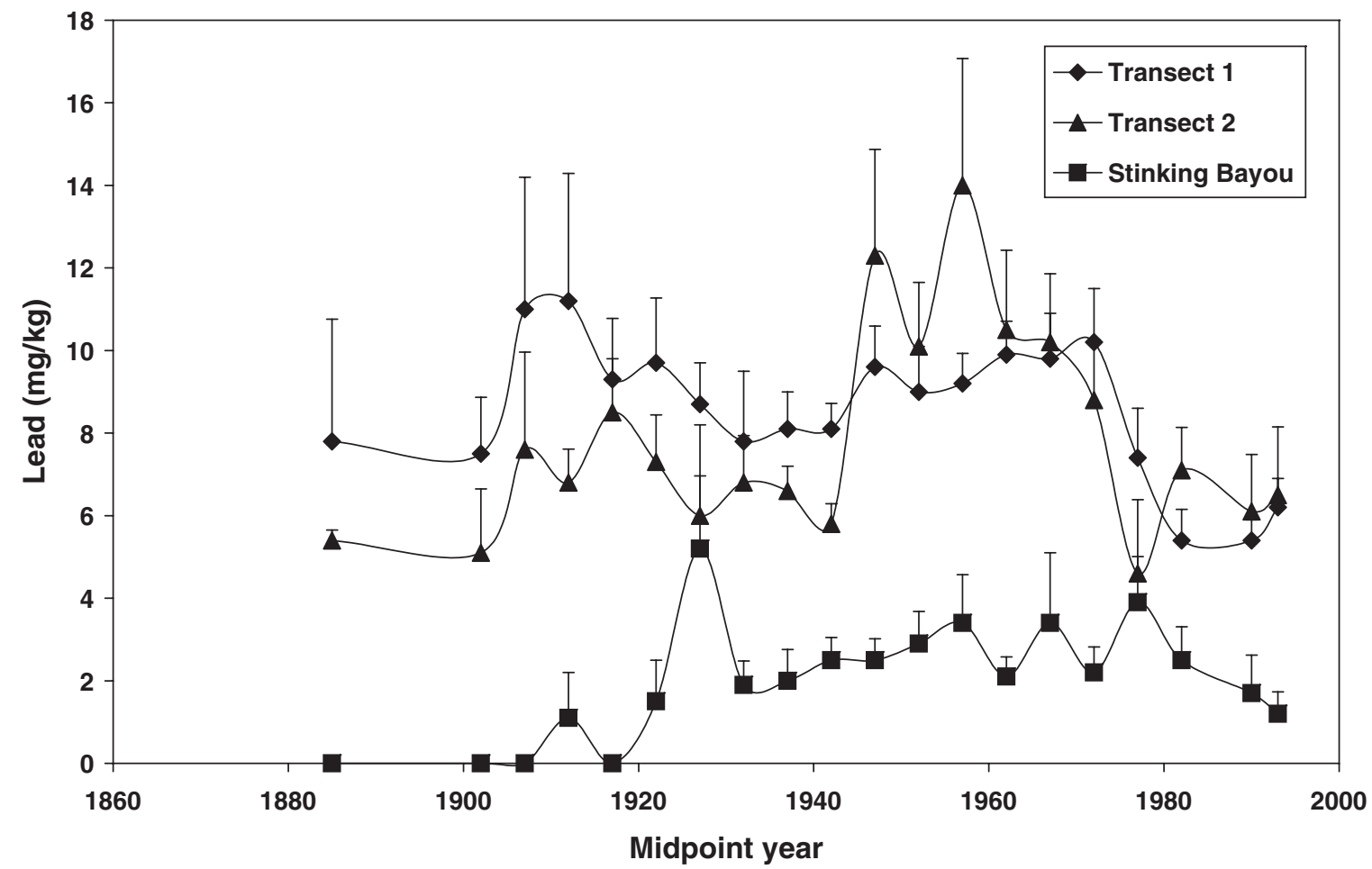

Fig. 6. Profile of $\mathrm{Pb}$ in tree rings of baldcypress along Transects 1 and 2 running perpendicular to Bayou Trepagnier into the adjacent cypress-tupelo community, and Stinking Bayou, a bayou that empties into Lake Pontchartrain $35 \mathrm{~km}$ north of Bayou Trepagnier. Error bars indicate standard error. The level of $\mathrm{Pb}$ in trees along Stinking Bayou, the reference area, was significantly different from the levels in trees along the two transects (see Table 2). The detection limit is $1 \mathrm{mg} / \mathrm{kg}$. 
and $\mathrm{Pb}$ is released into the water column. Lead can also be mobilized as suspended particulates in the water column. Plants can absorb $\mathrm{Pb}$ from the water column or at the root zone. Breakdown of $\mathrm{Pb}$ sulfides by sulfideoxidizing bacteria can mobilize $\mathrm{Pb}$ in the soil or in mudflats, and perhaps increase its bioavailability to plants. In addition, $\mathrm{Pb}$ in pore water may be transported into the bayou by advective flow in the vadose zone. In contrast, spoil bank soils do not contain acid volatile sulfides (Flowers et al., 1996).

Marcantonio et al. $(1998,2000)$ indicated that $\mathrm{Pb}$ uptake is occurring through the roots rather than through the leaves. Uptake by roots is considered the major pathway by which metals enter trees (Watmough and Hutchinson, 2003), but there may be active uptake by the mycorrhizal fungal associates of roots as well (Heggo et al., 1990) and even passive absorption with water uptake (Marschner, 1995).

The surrounding environment influences metal availability. For example, Guyette et al. (1991) reported that $\mathrm{Pb}$ and $\mathrm{Cd}$ were found only in growth rings of trees grown on acid soils and not on basic soils. Environmental parameters on the spoil bank and in the cypresstupelo swamp are different and may favor greater $\mathrm{Pb}$ uptake by the roots of the baldcypress trees in the swamp. During dry periods, sulfides in the bottom sediments of Bayou Trepagnier are exposed in mud flats, and may be oxidized, generating sulfuric acid and releasing $\mathrm{Pb}$ in the water column. Anomalous dissolved $\mathrm{Pb}$ values were recorded in the water in June 1995, a dry month. When a dry spell ends, the water is spread in the swamp The shallow ponds, cypress-tupelo swamps and marshes are more aquatic than the natural levees and spoil banks of Bayou Trepagnier, and $\mathrm{Pb}$ may be in a more favorable state for uptake by plants. The bases of baldcypress trees in this environment are completely submerged in water $(6 \mathrm{~cm}-0.5 \mathrm{~m})$ during most of the year, except in times of drought or perhaps for a month or so in the fall, while the spoil bank and likely most of the fine roots of the vegetation growing there, are above the water.

In summary, baldcypress trees growing in heavily contaminated spoil bank soil along Bayou Trepagnier accumulate less $\mathrm{Pb}$ than baldcypress growing in the adjoining swamp with less polluted soil. Lead in spoil bank soils is mobilized by surface runoff and contact with bayou water, causing sporadic dispersal into the swamp, where the soil is flooded most of the year.

Lead may be more mobile in baldcypress-tupelo swamps than in other forested ecosystems. We plan to analyze more cores from the Bayou Trepagnier ecosystem and other areas to test this hypothesis further. We seek to clearly define the hydrologic mechanisms of $\mathrm{Pb}$ release from soils and uptake into swamp trees. We also plan to core the same trees again to assess any translocation effects on $\mathrm{Pb}$ profiles.

\section{ACKNOWLEDGMENTS}

Tom Dell provided a statistical review and Franco Marcantonio and David White also reviewed the manuscript. We thank all of them for helpful suggestions and comments. We thank Kim Le, Sukanya Koppolu, and Joe McCollum for help with the study.

\section{REFERENCES}

Anderson, S., A.H. Chappelka, D.M. Flynn, and J.W. Odom. 2000. Lead accumulation in Quercus nigra and Q. velutina near smelting facilities in Alabama, USA. Water Air Soil Pollut. 118:1-11.

Baes, C.F., III, and S.B. McLaughlin. 1984. Trace elements in tree rings: Evidence of recent and historical air pollution. Science 224: 494-497.

Baes, C.F., III, and H.L. Ragsdale. 1981. Age-specific lead distribution in xylem rings of three tree genera in Atlanta, Georgia. Environ. Pollut. 2:21-35.

Bondietti, E.B., C.F. Baes, III, and S.B. McLaughlin. 1989. Radial trends in cation ratios in tree rings as indicators of the impact of atmospheric deposition of forests. Can. J. For. Res. 19:586-594.

Cutter, B., and R. Guyette. 1993. Anatomical, chemical and ecological factors affecting tree species choice in dendrochemistry studies. J. Environ. Qual. 22:611-619.

Di Toro, D.M., J.D. Mahony, D.J. Hansen, K.J. Scott, M.B. Hicks, S.M. Mayr, and M.S. Redmond. 1991. Toxicity of cadmium in sediments: The role of acid volatile sulfide. Environ. Toxicol. Chem. 9:1489-1504.

Donnelly, J.R., J.B. Shane, and P.G. Schaberg. 1990. Lead mobility within the xylem of red spruce seedlings: Implications for the development of pollution histories. J. Environ. Qual. 19:268-271.

Flowers, G.C., J. Clymire, L.V. Koplitz, G. McPherson, and S. Adams. 1997. Characterization of contaminant loadings in the Bayou Trepagnier watershed. Characterization, fate and transport, ecological effects and risk analysis. 14 July 1997. Department of Energy, New Orleans, LA.

Flowers, G.C., R. Blake, G. McPherson, R. Gonzalez, M. Devall, J. Whitbeck, L. Thien, and T. Bianchi. 1996. Process dynamics of $\mathrm{Pb}$ transport and plant uptake in Bayou Trepagnier. Proposal Tulane/ Xavier: Hazardous Materials in Aquatic Environments of the Mississippi River Basin, New Orleans, LA.

Forget, E., and J. Zayed. 1995. Tree-ring analysis for monitoring pollution by metals. In T.E. Lewis (ed.) Tree rings as indicators of ecosystem health. CRC Press, Boca Raton, FL.

Gambrell, R.P. 1994. Trace and toxic metals in wetlands-a review. J. Environ. Qual. 23:883-891.

Gilfrich, J.V., N.L. Gilfrich, E.F. Skelton, J.P. Kirkland, S.B. Quadri, and D.J. Natel. 1991. X-ray fluorescence analysis of tree rings. XRay Spectrom. 20:161-212.

Guyette, R.P., and E.A. McGinnes, Jr. 1987. Potential in using elemental concentrations in radial increments of old growth easternredcedar to examine the chemical history of the environment. p. 671-680. In G.C. Jacoby and J.W. Hornbeck (compilers) Proc. of the Int. Symp. on ecological aspects of tree ring analysis. U.S. Dep. of Energy CONF-8608144, Tarrytown, NY. 17-21 Aug. 1986. Natl. Tech. Info. Serv., Springfield, VA.

Guyette, R.P., B.E. Cutter, and G.S. Henderson. 1991. Long-term correlations between mining activity and levels of lead and cadmium in tree-rings of eastern red-cedar. J. Environ. Qual. 20:146-150.

Heggo, A., J.S. Angle, and R.L. Chaney. 1990. Effects of vesiculararbuscular mycorrhizal fungi on heavy metal uptake by soybeans. Soil Biol. Biochem. 22:865-869.

Hughes, M.K. 1981. Cycling of trace metals in ecosystems. p. 95-118. In N.W. Lepp (ed.) The effects of heavy metal pollution on plants. Vol. 2. Applied Sci. Publ., New York.

Kocman, V., T.E. Peel, and G.H. Tomlinson. 1991. Rapid analysis of macro and micro nutrients in leaves and vegetation by automated $\mathrm{x}$ ray fluorescence spectrometry (a case study of an acid-rain affected forest). Comun. Soil Sci. Plant Anal. 22:(19\&20):2063-2075.

Latimer, S.D., M.S. Devall, C. Thomas, E.G. Ellgaard, S.D. Kumar, and L.B. Thien. 1996. Dendrochronology and heavy metal deposition in tree rings of baldcypress. J. Environ. Qual. 25:1411-1419.

Lepp, N.W., and G.J. Dollard. 1974. Studies on the behavior of lead in wood. Binding of free and complexed ${ }^{210} \mathrm{~Pb}$ to xylem tissue. Oecologia 16:369-373.

Lewis, T.E. 1995. Tree rings as indicators of ecosystem health. CRC Press, Boca Raton, FL.

Louisiana Department of Environmental Quality. 1989. Impact of 
Bayou Trepagnier. Office of Water Resources Rep. OWR/02/89/ 001. Louisiana Dep. of Environ. Quality, Baton Rouge, LA.

MacLauchlan, L.E., J.H. Borden, M.R. Cackette, and J.M. D'Auria 1987. A rapid, multisample technique for detection of trace elements in trees by energy-dispersive X-ray fluorescence spectroscopy. Can. J. For. Res. 17:1124-1130.

Marcantonio, F., G.C. Flowers, L. Thien, and E.G. Ellgaard. 1998. Lead isotopes in tree rings: Chronology of pollution in Bayou Trepagnier. Environ. Sci. Technol. 32:2371-2376.

Marcantonio, F., G.C. Flowers, and N. Templin. 2000. Lead contamination in a wetland watershed: Isotopes as fingerprints of pollution. Environ. Geol. 39:1070-1076.

Marschner, H. 1995. Mineral nutrition of higher plants. 2nd ed. Academic Press, London.

Martin, M.H., and R.J. Bullock. 1994. The import and fate of heavy metals in an oak woodland ecosystem. p. 327-365. In S.M. Ross (ed.) Toxic metals in soil-plant systems. John Wiley \& Sons, New York.

Nriagu, J.O. 1990. Global metal pollution - poisoning of the biosphere. Environment 32:7-33.

Padilla, K.L., and K.A. Anderson. 2002. Trace element concentration in tree-rings biomonitoring centuries of environmental change. Chemosphere 49:575-585.

Pearson, C.E., W.D. Reeves, and A.R. Saltus, Jr. 1993. Remote sensing survey of the Bayou LaBranche wetlands restoration borrow area, St. Charles Parish, Louisiana. Cultural Resources Ser. Rep. COELMN/PO-93/06. U.S. Army Corps of Engineers, New Orleans District, New Orleans, LA.
Symeonides, C. 1979. Tree-ring analysis for tracing history of pollution: Application to a study in northern Sweden. J. Environ. Qual. 8:482-486.

Thomas, C.D., S.D. Latimer, O.P. Mills, and K.H.N. Le. 1996. p. 647658. In J.S. Dean et al. (ed.) Dendrochemistry of loblolly pine and cypress cores: Initial results for forest health monitoring. Tree rings, environment and humanity: Proc. of the Int. Conf., Tucson, AZ. 1721 May 1994. Radiocarbon, Tucson, AZ.

Turekian, K.K., and K.H. Wedepohl. 1961. Distribution of the elements in some major units of the Earth's crust. Geol. Soc. Am. Bull. 72:175-191.

Van Deusen, P. 1993. Dynaclim Version 3.2 users manual. USDA Forest Service, Southern Forest Exp. Stn., Inst. for Quantitative Studies, New Orleans, LA.

Watmough, S.A. 1999. Monitoring historical changes in soil and atmospheric trace metal levels by dendrochemical analysis. Environ. Pollut. 106:391-403.

Watmough, S.A., and T.C. Hutchinson. 2003. A comparison of temporal patterns in trace metal concentration in tree rings of four common European tree species adjacent to a $\mathrm{Cu}-\mathrm{Cd}$ Refinery. Water Air Soil Pollut. 146:225-241.

Wimmer, R., and S.B. McLaughlin. 1996. Possible relationships between chemistry and mechanical properties in the microstructure of red spruce xylem. p. 659-668. In J.S. Dean et al. (ed.) Dendrochemistry of loblolly pine and cypress cores: Initial results for forest health monitoring. Tree rings, environment and humanity: Proc. of the Int. Conf., Tucson, AZ. 17-21 May 1994. Radiocarbon, Tucson, AZ. 